\title{
IN VITRO PROPAGATION OF CEDAR (Cedrela odorata L.) FROM JUVENILE SHOOTS
}

\author{
Rolando García-Gonzáles $^{1^{*}}$, Miladys Delgado², Yailín González ${ }^{2}$, Aníbal González², Miguel Garriga ${ }^{3}$, \\ Peter D.S. Caligari ${ }^{3}$, Basilio Carrasco ${ }^{4}$, and Karla Quiroz ${ }^{1}$
}

Cedrela odorata $\mathrm{L}$. is one of the most important timber species currently traded in the Caribbean and Central America; however, it has been intensively exploited. In vitro techniques and clonal propagation can help to develop new plantations and assist in establishing improvement programs for this species. The aim of this study was to develop a protocol to establish in vitro conditions and to micropropagate this species from nodal explants from juvenile cuttings taken from field trees. Disinfection of node explants with 5\% propiconazole CE 25 during 3 min resulted in 100\% explant disinfection and $60 \%$ morphogenic response on those established explants. Shoot development was optimized by cultivating in vitro node explants in Murashige and Skoog basal medium supplemented with $2 \mathrm{mg} \mathrm{L}^{-1}$ 6-bencilaminopurine and $3 \mathrm{mg} \mathrm{L}^{-1}$ naphthaleneacetic acid. This medium resulted in $100 \%$ shoot development from the in vitro node explants with a $3.93 \mathrm{~cm}$ mean height. Rooting was also stimulated $6 \mathrm{wk}$ after individualization of the regenerated plants on the same micropropagation medium with a mean of 3.9 roots per plant. In vitro plants did not show morphologic differences when compared to ex vitro seeds.

Key words: Organogenesis, in vitro propagation, Cedrela odorata, in vitro rooting, plant growth regulators.

$C$ edrela odorata L. (cedar, red cedar, Cuban cedar, and Mexican cedar) is a high-value timber species that has been considered vulnerable because of intense exploitation of its natural populations and the lack of intensive propagation systems allowing the establishment of commercial plantations (Cintron, 1990; Patiño, 1997; Plasencia, 1998). In the Americas, the development of hardwood plantations of the Meliaceae family (C. odorata and Mahogany) is limited because of the long life cycles of these species, their susceptibility to pest attack, and the lack of farmer interest to plant species with profits in the long term (Ramos, 1998; Pérez, 2006). Moreover, the current propagation of this species is not supporting the fast reproduction in natural forests to sustain its increased demand.

In vitro techniques applied to clonal propagation can help mitigate these drawbacks and provide farmers with high quality planting material (Yanchuk, 2000; Sasson, 2001). The use of modern in vitro techniques on woody

${ }^{1}$ Universidad Católica del Maule, Facultad de Ciencias Agrarias y Forestales, Campus San Miguel. Av. San Miguel 3605, Casilla 617, Talca. .Corresponding author (rgarciag@ucm.cl).

${ }^{2}$ Estación Experimental Forestal de Camagüey, P.O. Box 405, C.P. 70100, Camagüey, Cuba.

${ }^{3}$ Universidad de Talca, Instituto de Biología Vegetal y Biotecnología, 2 Norte 845, Talca, Chile.

${ }^{4}$ Pontificia Universidad Católica de Chile, Facultad de Agronomía e Ingeniería Forestal, Vicuña Mackenna 4860, Casilla 306, Correo 22, Santiago, Chile.

Received: 2 September 2010.

Accepted: 15 June 2011. trees has brought new possibilities not only for rapid tree species multiplication, but also for ex situ conservation of important germplasms (Husain et al., 2008).

Together with providing multiplication in a limited time and space, in vitro propagation of plants (micropropagation) avoids the limitations of the long regeneration cycle of ligneous species and reduces the dependence on sexual reproduction (García-Gonzáles et al., 2010). However, in vitro culture of woody species is considered very difficult to achieve due to the low regeneration potential of woody tissues and contaminant microorganisms that affect morphogenic efficiency and plant recovery (Husain and Anis, 2009). On the other hand, phenolic compound production from woody tissues also interferes during explant establishment, and phenol production interferes with morphogenetic processes (Husain and Anis, 2009).

Advances in plant micropropagation of $C$. odorata are not still in depth (Pérez et al., 2002). Discrete results for $C$. odorata micropropagation using apical buds and nodal segments, isolated from juvenile plants generated from seeds, have already been achieved (Maruyama et al., 1989a; 1989b; Orellana, 1997; Pérez et al., 2002; Rodríguez et al., 2003; Maruyama, 2006; Pérez, 2006). However, it has been found that $C$. odorata is characterized for its recalcitrance to in vitro culture due to bacteria and fungi, an oxidative response of in vitro tissues after disinfection, and low morphogenic response of explants (Maruyama, 1989b; Pérez et al., 2002).

Morphogenic response in $C$. odorata has been benefited by adding cytokinins to the culture medium 
and combining auxins and cytokinins in different concentrations (Maruyama et al., 1989a; Pérez et al., 2002). Rooting of $C$. odorata under in vitro conditions has been achieved by supplementing the basal medium with auxins (Pérez et al., 2006). Similarly, it was found that the mineral composition of the basal medium can be a significant factor in the morphogenic response of in vitro $C$. odorata plants (Pérez, 2006) and Cedrela fisilis, a species from the same genus (Costa Nunes et al., 2002).

Along with the abovementioned results, fundamental studies have been developed in very young plants, which limit their application in breeding programs based on the selection and multiplication of promising clones. Pérez (2006) found that the morphogenic response of in vitro tissues from 10-yr-old plants was variable; moreover, morphogenic response of the established tissues could depend on the juvenility of the donor plant tissues. Therefore, this study was conducted to establish a protocol for in vitro establishment and micropropagation of $C$. odorata from juvenile shoots taken from field trees.

\section{MATERIALS AND METHODS}

\section{Plant material}

Plant material was obtained from adult $C$. odorata plants previously located at the Seed Farm (21 $20^{\circ}$ N , $77^{\circ} 52^{\prime}$ W) of the Experimental Agroforestry Station in the eastern Cuban province of Camagüey. The trees were 10 to $12 \mathrm{yr}$ old with a mean height of $12 \mathrm{~m}$.

\section{Establishment of $C$. odorata from buds with shoot development}

Cuttings were prepared from juvenile seasonal shoots to induce shoot development. They were placed in a sterile water solution containing $5 \mathrm{mg} \mathrm{L}^{-1}(22.2 \mu \mathrm{M})$ of 6-bencilaminopurine and maintained during $3 \mathrm{wk}$ at 25 $\pm 1{ }^{\circ} \mathrm{C}$ under a $12: 12 \mathrm{~h}$ photoperiod. Light intensity was regulated to $50 \mu \mathrm{mol} \mathrm{m} \mathrm{m}^{-2} \mathrm{~s}^{-1}$ in the growing chamber.

\section{Evaluation of different bud disinfection methods}

To introduce and establish in vitro $C$. odorata, juvenile shoots were selected from previously induced cuttings. Shoots up to $5 \mathrm{~cm}$ long were selected and extracted from the cuttings and prepared as 1.0- to $1.5-\mathrm{cm}$ long nodals. For nodal surface disinfection of nodal segments, the following conditions were evaluated: 1) Sodium hypochlorite solution at 1 and 5\% during 10, 20, and $30 \mathrm{~min}$; and 2) propiconazole CE 25 solution ( $(2 R S, 4 R S ; 2 R S, 4 S R)-1$-[2(2,4-dichlorophenyl)-4-propyl-1,3-dioxolan-2-ylmethyl]1H-1,2,4-triazole, Tilt, Syngenta Monthey AG, Monthey, Switzerland) at 1 and 5\% during 3, 5, and $10 \mathrm{~min}$.

The percentages of disinfected explants, shoot survival, shoot development from buds, and shoot rooting were evaluated.

For all the experiments, plant material was washed with detergent water for $15 \mathrm{~min}$, and then washed three times with distilled sterile water. Tissues were dried on absorbent paper for $10 \mathrm{~min}$ and then established in the shoot development medium. Each treatment was replicated three times with 10 nodal segments per replicate. The homogeneity of the variance was determined through the Bartlett Test $(\alpha=0.05)$. Percentage data were transformed according to the expression $y=\sqrt{ } x$. For the processing and analysis of the results an ANOVA and the Tukey HSD multiple range test $(\mathrm{p}=0.05)$ were carried out in order to compare treatment means. All the statistical analyses were carried out with the Statgraphics Plus 5.0 software (StatPoint, Warrenton, Virginia, USA).

Disinfected nodal explants were established in MS (Murashige and Skoog, 1962) basal medium supplemented with $2 \mathrm{mg} \mathrm{L}^{-1}(8.88 \mu \mathrm{M})$ 6-bencilaminopurine (BAP), 30 $\mathrm{g} \mathrm{L}^{-1}$ sucrose, and $\mathrm{pH}$ was adjusted between 5.6 and 5.7 according to the recommendation for this species (Pérez et al., 2002). Initial explants were maintained during 12 wk under a 12:12 h photoperiod and $100 \mu \mathrm{mol} \mathrm{m} \mathrm{m}^{-2} \mathrm{~s}^{-1}$ light intensity. Room temperature was maintained at $25 \pm 1{ }^{\circ} \mathrm{C}$.

Effect of different culture media on shoot induction and rooting of in vitro $C$. odorata plantlets

For the multiplication step, the effect of indoleacetic acid (IAA) and naphthaleneacetic acid (NAA) at three concentrations on node and leaf formation, plant height, and rooting was evaluated. These parameters are decisive in establishing a micropropagation method when the multiplication rate is based on pre-existing buds from nodal segments.

Nodal segments were taken from 12-wk-old shoots induced in modified MS basal medium as already described. For shoot induction and efficient plant elongation, this medium was supplemented with the following auxin treatments: 1) IAA $1.0 \mathrm{mg} \mathrm{L}^{-1}(5.70 \mu \mathrm{M})$; 2) IAA $2.0 \mathrm{mg} \mathrm{L}^{-1}(11.42 \mu \mathrm{M})$; 3) IAA $3.0 \mathrm{mg} \mathrm{L}^{-1}$ (17.12 $\mu \mathrm{M})$; 4) NAA $1.0 \mathrm{mg} \mathrm{L}^{-1}(5.37 \mu \mathrm{M})$; 5) NAA $2.0 \mathrm{mg} \mathrm{L}^{-1}$ (10.7 $\mu \mathrm{M})$; and 6) NAA $3.0 \mathrm{mg} \mathrm{L}^{-1}(16.07 \mu \mathrm{M})$.

Explants were prepared as uninodal or binodal segments depending on size, approximately $5 \mathrm{~mm}$ long. These segments were cultured in their respective treatments at a $12: 12 \mathrm{~h}$ photoperiod, $100 \mu \mathrm{mol} \mathrm{m} \mathrm{m}^{-2} \mathrm{~s}^{-1}$ light intensity, and $25 \pm 1{ }^{\circ} \mathrm{C}$. Sucrose concentration in the basal medium was increased in this step to $50 \mathrm{~g} \mathrm{~L}^{-1}$. Thirty nodal explants were evaluated per treatment, which were subcultured with a 4-wk frequency until the experiment's final evaluation. To induce root formation, developed shoots were separated from the original nodal segment and cultured in their respective culture medium without eliminating leaves and no explant manipulation.

Evaluating the number of nodal segments, leaf emission, and shoot height was carried out after an 8-wk culture of the nodal segments in each culture media. Root formation was evaluated after $6 \mathrm{wk}$ from the time plants were individualized. Plant height was determined with graph paper; explants were placed on the paper, the initial 
start of plant shoot development was established as the basal side, and the apical bud of the shoot as the superior point. Results were processed and analyzed by ANOVA and the Tukey HSD multiple range test $(p=0.05)$ in order to compare treatment means. All the statistical analyses were carried out with the Statgraphics Plus 5.0 software (StatPoint, Warrenton, Virginia, USA).

\section{RESULTS AND DISCUSSION}

\section{Effectiveness of disinfection methods}

Disinfection of $C$. odorata buds behaved in a complex way (Table 1), and coincided with previously documented results (García et al., 2004; Pérez et al., 2006). The 30min disinfection with sodium hypochlorite at 1 and $5 \%$, although effective for disinfection, produced tissue oxidation and death of all disinfected nodal segments. Washing the explants with sodium hypochlorite at $1 \%$ for 20 min yielded the best results with bud survival percentages significantly higher than the other treatments. Nevertheless, the percentage of bud disinfection diminished significantly and neither root formation nor shoot development of the nodal segments showed significant differences with the other sodium hypochlorite treatments.

Phytotoxicity symptoms, as a result of sodium hypochlorite treatment, were also observed as tissue depigmentation with progressive discoloration that was not recovered even in light conditions.

Eliminating the microorganism with Propiconazole CE 25 increased explant survival, shooting and rooting percentages as compared to the sodium hypochlorite treatments (Table 1). Shoot induction and development from buds occurred in $60 \%$ of the explants that survived the disinfection step; rooting was also observed in $40 \%$ of the explants. In both cases, results were statistically higher than the other treatments.

Treatments with high concentrations of propiconazole did not produce death as a result of tissue oxidation. Bud death was observed after depigmentation and a total or sectorized chlorosis of the tissue. The main losses caused

Table 1. Effectiveness of different disinfectants at different concentrations and exposure time on the disinfection and in vitro establishment of Cedrela odorata vegetative buds. Data were taken 16 wk after node establishment under in vitro conditions.

\begin{tabular}{lcccc}
\hline & $\begin{array}{c}\text { Mean of } \\
\text { disinfected } \\
\text { Treatment } \\
\text { nodal segments }\end{array}$ & Survival & Rooting & $\begin{array}{c}\text { Shoot } \\
\text { development }\end{array}$ \\
\hline A & $7.00 \pm 1.00 \mathrm{~b}$ & $13.09 \pm 12.54 \mathrm{~b}$ & $8.33 \pm 14.43 \mathrm{a}$ & $13.09 \pm 12.54 \mathrm{ab}$ \\
$\mathrm{B}$ & $10.00 \pm 0.0 \mathrm{c}$ & $0 \mathrm{a}$ & $0 \mathrm{a}$ & $0 \mathrm{a}$ \\
$\mathrm{C}$ & $10.00 \pm 0.0 \mathrm{c}$ & $0 \mathrm{a}$ & $0 \mathrm{a}$ & $0 \mathrm{a}$ \\
$\mathrm{D}$ & $10.00 \pm 0.0 \mathrm{c}$ & $0 \mathrm{a}$ & $0 \mathrm{a}$ & $0 \mathrm{a}$ \\
$\mathrm{E}$ & $5.33 \pm 0.58 \mathrm{a}$ & $62.22 \pm 3.85 \mathrm{c}$ & $37.78 \pm 3.85 \mathrm{~b}$ & $37.78 \pm 3.85 \mathrm{c}$ \\
$\mathrm{F}$ & $10.00 \pm 0.0 \mathrm{c}$ & $60 \pm 0.0 \mathrm{c}$ & $40 \pm 10.00 \mathrm{~b}$ & $50 \pm 0.0 \mathrm{c}$ \\
$\mathrm{G}$ & $10.00 \pm 0.0 \mathrm{c}$ & $60 \pm 10.00 \mathrm{c}$ & $30 \pm 10.00 \mathrm{~b}$ & $33.33 \pm 11.55 \mathrm{bc}$ \\
$\mathrm{H}$ & $10.00 \pm 0.0 \mathrm{c}$ & $46.67 \pm 5.77 \mathrm{c}$ & $26.67 \pm 11.55 \mathrm{~b}$ & $30.00 \pm 10.00 \mathrm{bc}$ \\
\hline Treatments A to D: Sodium hypochlorite $1 \%(\mathrm{~A}, 20 \mathrm{~min})(\mathrm{C}, 30 \mathrm{~min}) ; 5 \%(\mathrm{~B}, 20 \mathrm{~min})(\mathrm{D}$, \\
30 min). Treatments E to H: propiconazole CE 25 1\% (E, 3 min) $(\mathrm{G}, 5$ min); $5 \%(\mathrm{~F}, 3 \mathrm{~min})$ \\
(H, 5 min). Different letters mean that there are differences among treatments. ANOVA, \\
Tukey HDS Test (p<0.05). $\mathrm{n}=3$.
\end{tabular}

by contamination occurred during the first week, and fungi and bacteria were the main contaminant agents that were apparently of environmental origin or present on the tissue surface. In subsequent propagation cycles, the presence of endogen contaminants in the in vitro plant material was not observed.

\section{Morphogenic response of $C$. odorata nodes under different PGR treatments}

Effect of PGR on leaf and stem development. Morphogenic response and plant development showed a direct relationship in the culture mediums with the best results (Figure 1). Treatments with $17.12 \mu \mathrm{M}$ IAA, 10.7 $\mu \mathrm{M}$, and $16.07 \mu \mathrm{M}$ NAA induced the best leaf formation and stem development with significant differences with other treatments (Figure 1A). In these media, it
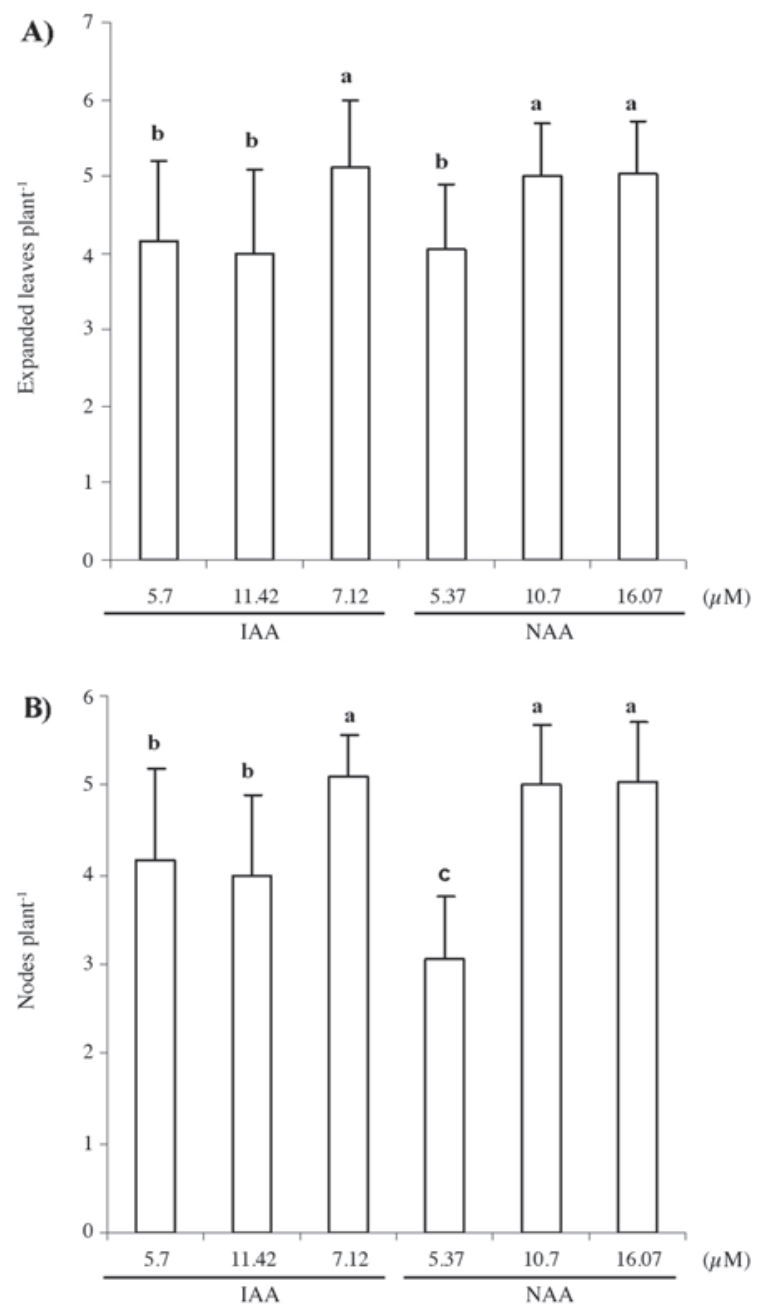

Data were taken $8 \mathrm{wk}$ after node establishment. Different letters mean that there are significant differences among treatments. Tukey Test HSD $(p>0.05) n=30$.

Figure 1. Effect of interaction of different concentrations of indole-3-acetic acid (IAA) or naphtaleneacetic acid (NAA) with 6-bencilaminopurine (BAP) $(8.88 \mu \mathrm{M})$ on the morphogenic response of Cedrela odorata juvenile nodal segments under in vitro conditions. (A) Leaf emission. (B) Nodal segment emission. 
was observed that the leaf lamina of the in vitro plants developed better, and it is probable that this effect is related to a better photosynthetic efficiency that has influenced plant development and higher rooting. In the case of the $17.12 \mu \mathrm{M}$ IAA treatment, a similar number of leaves was observed with regards to the treatments with the best results. Likewise, the number of nodal segments was benefited more in the treatments supplemented with $17.12 \mu \mathrm{M}$ IAA and NAA at 10.7 and $16.07 \mu \mathrm{M}$, and differed significantly from the other treatments (Figure 1B). The greater number of nodal segments can benefit a higher multiplication rate and greater efficiency of the in vitro propagation protocol. In woody species, propagation from nodal segments can be limited by the low nodal formation and scarce separation of these, which complicates its manipulation. For Melia azedarach L., a good response has been obtained in nodal segments cultured in MS medium supplemented with IAA (0.06 $\mu \mathrm{M})$ and BAP $(4.44 \mu \mathrm{M})$, as well as with IAA and kinetin (4.65 $\mu \mathrm{M})$ (Thakur et al., 1998).

Nevertheless, morphogenic response in $C$. odorata has been obtained with relatively low cytokinin levels (Pérez et al., 2002; Pérez, 2006). In the case of somatic embryogenesis, embryo germination was achieved with lower concentrations of both growth regulators (Muñoz Tuesta, 2003). For S. macrophylla, it was found that $0.5 \mathrm{mg} \mathrm{L}^{-1}(2.46 \mu \mathrm{M})$ of indole-3-butyric acid (IBA) did not have a significant influence on shoot production and stem development compared with cytokinin 2-isopentenyladenine (2-iP) at different concentrations. It was also found that there was no significant effect of the interactions between these two regulators on the morphogenic response of this Meliaceae species (Flores, 2001).

The morphogenic response exhibited by $C$. odorata plants in this study could be related to three fundamental factors: 1) influence of the genotype; 2) explants originated from plants maintained in basal MS medium without any growth regulators, the regulator interactions introduced to the medium may have affected the endogen balance of growth regulators, and consequently, the response to the evaluated morphogenic processes; and 3) the juvenile state of the starting shoots (Figure 2) can determine

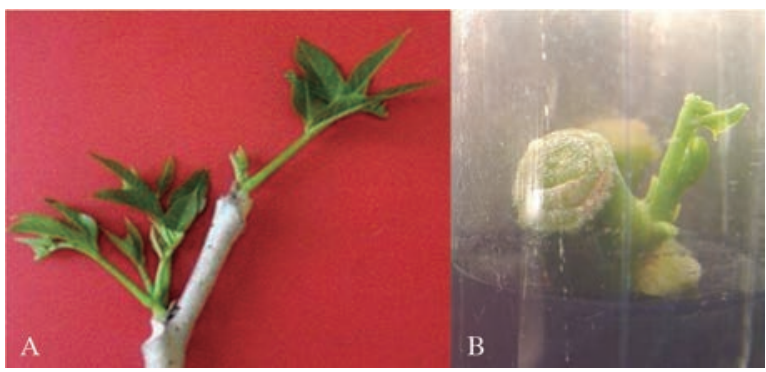

Figure 2. Explant source (A) for in vitro disinfection and establishment of Cedrela odorata juvenile shoots and morphogenic development of established explants $10 \mathrm{~d}$ after being planted (B). oxidant compound emission that affects the morphogenic response. It has been documented that the relationship between cytokinin and auxin endogen concentrations play a more important role in differentiation and elongation than the net concentrations of these hormones present in the culture medium (Centeno et al., 2003), and it is therefore probable that this relationship is optimum in the treatments with the best results.

Plantlet elongation and rooting under different PGR treatments. The influence of the different culture media on elongation showed a greater difference in all treatments. As shown in Figure 3, the mean height in the treatment supplemented with $3 \mathrm{mg} \mathrm{L}^{-1} \mathrm{NAA}$ was significantly greater than in the other treatments and had a mean height of $3.93 \mathrm{~cm}$. It has been observed in C. odorata that BAP induces tissue differentiation more effectively than stem elongation when applied individually in the culture medium (Pérez, 2006). In the treatments with a low auxin level in the basal medium $(5.70 \mu \mathrm{M}$ IAA $1.0 \mathrm{mg}$ $\mathrm{L}^{-1} ; 11.42 \mu \mathrm{M}$ IAA $2.0 \mathrm{mg} \mathrm{L}^{-1} ; 17.12 \mu \mathrm{M}$ IAA $3.0 \mathrm{mg} \mathrm{L}^{-1}$, and $5.37 \mu \mathrm{M}$ NAA $1.0 \mathrm{mg} \mathrm{L}^{-1}$ ) short internodal segments were generated.

Increasing NAA concentrations improved shoot height while IAA treatments had no significant effect, probably due to a more efficient synergism between NAA with

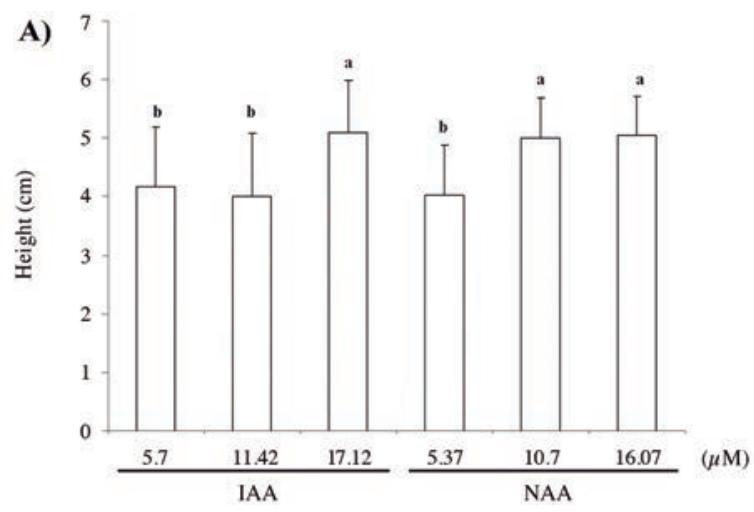

Different letters mean that there are significant differences among treatments. Tukey Test HSD $(\mathrm{p}>0.05) \mathrm{n}=30$.

B)

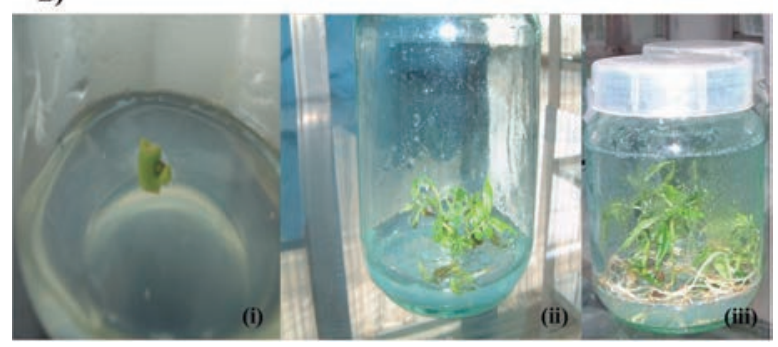

In vitro-established nodes $10 \mathrm{~d}$ after culture; (ii) morphogenic development from nodal segments $30 \mathrm{~d}$ after culture; (iii) morphogenic development $45 \mathrm{~d}$ after culture.

Figure 3. (A) Influence of indole-3-acetic acid (IAA) and naphthaleneacetic acid (NAA) at different concentrations, and 6-bencilaminopurine (8.88 $\mu \mathrm{M}$ ) interaction on in vitro Cedrela odorata plant height. (B) Explant size of a subcultured nodal segment. 
cytokinin and/or $C$. odorata endogen hormonal contents. It is possible that the interaction between BAP and IAA benefits cellular elongation at higher IAA levels than those evaluated in these experiments whereas the interaction between BAP and NAA can benefit differentiation at low NAA levels and cellular elongation at levels above $2 \mathrm{mg}$ $\mathrm{L}^{-1}(10.7 \mu \mathrm{M})$ when combined with BAP. On the other hand, this behavior can be associated with a better nutrient absorption because of the number of roots generated in the treatments and higher auxin concentrations. It was found in $C$. fissilis that the interaction between NAA $(2.5 \mu \mathrm{M})$ and BAP $(5 \mu \mathrm{M})$ increased plant elongation; however, a higher concentration of NAA reduced plant development when combined with BAP and when BAP was eliminated from the basal medium (Costa Nunes, 2002). The auxin:cytokinin ratio, displaced towards auxins, may have limited explant organogenic capacity (Centeno et al., 2003), thus benefiting apical dominance and internodal elongation.

For $C$. odorata nodal segments cultured in vitro from juvenile plants, $1 \mathrm{~cm}$ long shoots were obtained in basal MS medium supplemented with $2.2 \mu \mathrm{M}$ BAP although no significant differences were found with the other treatments with 2-iP and kinetin (Pérez et al., 2002). The best response for Melia azedarach L. was obtained for growth and nodal formation at low IAA levels while height was favored when IAA levels increased (Thakur et al., 1998). In S. macrophylla, the best nodal emission was obtained with BAP at $4 \mathrm{mg} \mathrm{L}^{-1}(17.76 \mu \mathrm{M})$, and adding NAA or IAA to the medium at different concentrations benefited root and plant height development (Astorga et al., 1996). Furthermore, de Schottz et al. (2007) found that high concentrations of BAP $(20 \mu \mathrm{M})$ and 2-iP $(2 \mu \mathrm{M})$ caused a significant reduction in plant development and internodal length, which affected the multiplication rate.

Treatments supplemented with $3 \mathrm{mg} \mathrm{L}^{-1}$ NAA and $3 \mathrm{mg} \mathrm{L}^{-1}$ IAA induced the best root formation; NAA treatments induced more efficiently than IAA when it was added to the basal media. There was a direct relationship between rooting and concentration increase of NAA and IAA (Figure 4).

Regenerated roots in the treatment supplemented with $2 \mathrm{mg} \mathrm{L}^{-1}$ NAA were more vigorous and pigmented along the side with a good formation of secondary short roots. Roots induced under $3 \mathrm{mg} \mathrm{L}^{-1}$ NAA showed partial tissue oxidation, which were probably due to the phytotoxic effect of some of the components of the basal culture medium. It was observed in $C$. odorata that the culture medium's mineral and sucrose composition had a significant effect on root formation and development (Pérez et al., 2006).

Previous studies demonstrated that $1 \mathrm{mg} \mathrm{L}^{-1}(5.37$ $\mu \mathrm{M})$ NAA benefited root emission in nodal segments introduced in vitro from seedlings previously germinated under greenhouse conditions (Pérez et al., 2006); however, no results were obtained from buds introduced from adult

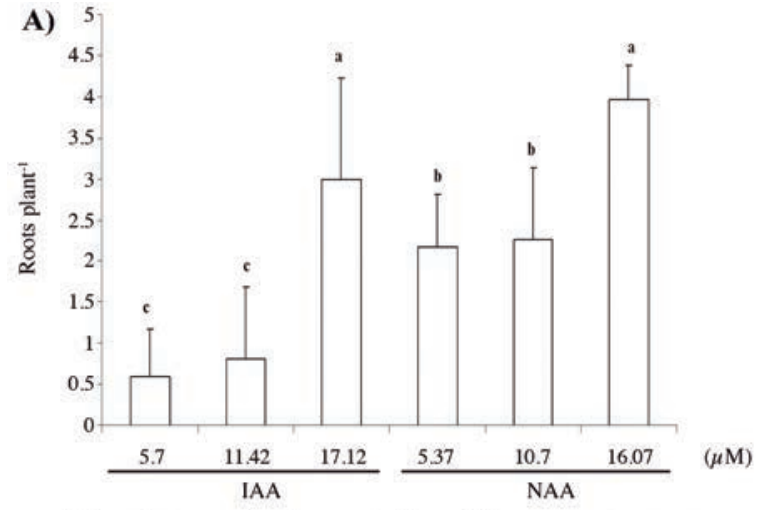

Different letters mean that there are significant differences among treatments. Tukey Test HSD $(\mathrm{p}>0.05) \mathrm{n}=30$

B)

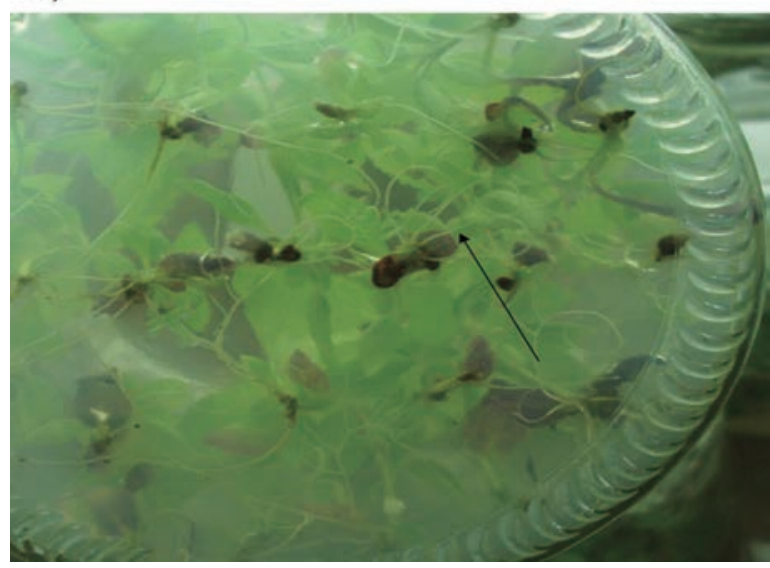

Figure 4. (A) Influence of indole-3-acetic acid (IAA) and naphthaleneacetic acid (NAA) at different concentrations, and bencilaminopurine $(8.88 \mu \mathrm{M})$ interaction on plant rooting of Cedrela odorata in vitro plants. (B) Root emission (black arrow) from micropropagated $C$. odorata plants $30 \mathrm{~d}$ after being planted in the rooting medium.

plants. It was also found that root induction from node segments derived from in vitro-germinated seeds was inhibited when BAP was added to the basal medium at 2.2 and $6.5 \mu \mathrm{M}$ (Pérez et al., 2002). For $C$. fissilis, a tree from the same genus, the best rooting was obtained when shoot explants were cultured in basal medium supplemented with $1.25 \mu \mathrm{M}$ IBA after $35 \mathrm{~d}$ of culture (Costa Nunes et al., 2002).

It has been documented for other woody species that the combination of BAP and kinetin from 0.1 up to $2 \mathrm{mg}$ $\mathrm{L}^{-1}$ combined with low levels of IBA $\left(0.1 \mathrm{mg} \mathrm{L}^{-1}, 0.5 \mu \mathrm{M}\right)$ benefited shooting, but rooting was stimulated only when the IBA concentration was higher than $1.5 \mathrm{mg} \mathrm{L}^{-1}$ (4.9 $\mu \mathrm{M})$ (Chalupa, 2003).

Root formation from adult plant tissues in the Meliaceae family has been difficult to achieve. Success with in vitro mahogany trees has been limited (Astorga et al., 1996), and for $C$. odorata rooting, it has only been successful with seedling-derived tissues or in vitro-germinated plants (Pérez et al., 2002; 2006). Organogenic formation of $S$. macrophylla roots was benefited by $5.0 \mathrm{mg} \mathrm{L}^{-1}(26.85$ 
$\mu \mathrm{M})$ NAA treatments for $5 \mathrm{~d}$ and a subsequent subculture in $2.0 \mathrm{mg} \mathrm{L}^{-1} \mathrm{NAA}(10.7 \mu \mathrm{M})$ for $4 \mathrm{wk}$ (Lopes et al., 2001) while treatments with IBA did not produce any interesting results.

\section{CONCLUSIONS}

Disinfection of $C$. odorata nodal segments using Propiconazole CE 25 allowed a high percentage of surface explant disinfection, explant survival, and an efficient morphogenic response from juvenile shoots. Adding $8.88 \mu \mathrm{M}$ BAP and 16.1 $\mu \mathrm{M}$ NAA to the basal medium induced a good morphogenic response in nodal segments during the micropropagation step. Plant rooting was successful under NAA treatments and might allow the $e x$ vitro culture of the micropropagated $C$. odorata plantlets. These results allowed developing a rapid protocol for in vitro establishment and micropropagation of $C$. odorata from juvenile shoots isolated from field trees.

Propagación in vitro de cedro (Cedrela odorata L.) a partir de brotes vegetativos juveniles. El cedro (Cedrela odorata L.) es una de las especies más importantes para el sector agroforestal caribeño y centroamericano pero se encuentra bajo una presión intensa de explotación debido a su alta demanda. Las técnicas de cultivo in vitro y propagación clonal pueden contribuir a atenuar este inconveniente y dotar a los productores con plantas de alta calidad genética y de ciclos biológicos y productivos más reducidos. El objetivo de este trabajo fue desarrollar un protocolo de establecimiento in vitro y micropropagar la especie a partir de segmentos nodales de estacas juveniles obtenidas de plantas de campo. El estudio de ocho métodos de desinfección dejó establecido que lavados de los segmentos nodales con propiconazol CE 25 al 5\% durante 3 min posibilita un 100\% de desinfección de los segmentos nodales y un $60 \%$ de brotación de las yemas. La adición de $2 \mathrm{mg} \mathrm{L}^{-1}$ de 6-bencilaminopurina y $3 \mathrm{mg}$ $\mathrm{L}^{-1}$ de ácido naftalenacético al medio basal Murashige y Skoog propició una brotación del 100\% de los segmentos nodales in vitro y una altura promedio de $3,93 \mathrm{~cm}$ a las 8 semanas. La misma concentración de reguladores del crecimiento propició la formación de 3,9 raíces por planta a las 6 semanas de individualizada. Las plantas adaptadas ex vitro no presentaron diferencias morfológicas con las plantas germinadas a partir de semillas.

Palabras clave: organogénesis, propagación in vitro, Cedrela odorata, enraizamiento in vitro, reguladores del crecimiento.

\section{LITERATURE CITED}

Astorga, C., M.E. Aguilar, and L. Pérez. 1996. Development of in vitro culture and conservation techniques for Swietenia macrophylla. Annual Report of the Centro Agronómico Tropical de Investigación y Enseñanza (CATIE), Turrialba, Costa Rica. p. 37-38. Biblioteca Conmemorativa Orton Instituto Interamericano de Cooperación para la Agricultura (IICA)/CATIE, Turrialba, Costa Rica.

Centeno, M.L., A. Rodríguez, I. Feito, R. Sánchez-Tamés, and B. Fernández. 2003. Uptake and metabolism of 6-benzyladenine and 1-naphthaleneacetic acid and dynamics of indole-3-acetic acid and cytokinins in two callus lines of Actinidia deliciosa differing in growth and shoot organogenesis. Physiologia Plantarum 118:579-588.

Chalupa, V. 2003. In vitro propagation of Tilia platyphyllos by axillary shoot proliferation and somatic embriogenesis. Journal of Forestry Science 49(12):537-543.

Cintron, B.B. 1990. Cedrela odorata L. Cedro hembra, Spanish cedar. p. 250- 257. In Burns, R.M., and B.H. Honkala (eds.) Silvics of North America: 2. Hardwoods Agriculture Handbook 654. US Department of Agriculture, Forest Service, Washington, D.C., USA.

Costa Nunes, E., C. Volkmer, F. Netto, and A.M. Viana. 2002. In vitro culture of Cedrela fissilis Vellozo (Meliaceae). Plant Cell Tissue and Organ Culture 70:259-268.

Flores, A. 2001. Establecimiento de las fases iniciales de la micropropagación de Caoba (Swietenia macrophylla King.) a partir de plantas de invernadero. Tesis M.Sc. Centro Agronómico Tropical de Investigación y Enseñanza (CATIE), Turrialba, Costa Rica.

García-Gonzáles, R., K. Quiroz, P.D.S. Caligari, and B. Carrasco. 2010. Plant tissue culture: Current status opportunities and challenges. Ciencia e Investigación Agraria 37(3):5-30.

García, R., Y. González, M. Delgado, E. Rodríguez, A. González, U. Peláez, et al. 2004. Introducción al cultivo in vitro de Cedro (Cedrela odorata L.). Memorias del II Congreso Forestal de Cuba, Ciudad de la Habana. 13-17 de Septiembre de 2004. Instituto de Investigaciones Forestales, Ciudad de la Habana, Cuba.

Husain, M.K., M. Anis, and A. Shahzad. 2008. In vitro propagation of a multipurpose leguminous tree (Pterocarpus marsupium Roxb.) using nodal explants. Acta Physiologiae Plantarum 30:353-359.

Husain, M.K., and M. Anis. 2009. Rapid in vitro multiplication of Melia azadarach L. (a multipurpose) woody tree. Acta Physiologiae Plantarum 31:765-772.

Lopes, S. da C., O. Alves, G.R. Luces, R. Cravo, and J.E. Brasil. 2001. In vitro rooting of Mahogany (Swietenia macrophylla King). CERNE 7(1):124-128.

Maruyama, E. 2006. Tissue culture of Swietenia macrophylla King (Big-Leaf Mahogany). p. 131-136. In Suzuki, K., K. Ishii, S. Sakurai, and S. Sasaki (eds.) Plantation technology in tropical forest science. Springer-Verlag, Tokio, Japan.

Maruyama, E., K. Ishii, A. Saito, and K. Migita. 1989a. Micropropagation of cedro (Cedrela odorata L.) by shoot-tip culture. Journal of the Japanese Forestry Society 71:329-333.

Maruyama, E., K. Ishii, A. Saito, and K. Migita. 1989b. Screening of suitable sterilization of explants and proper media for tissue culture of eleven tree species of Perú-Amazon forest. Journal of Agricultural Sicence (Japan) 33:252-260.

Muñoz Tuesta, S.Y. 2003. Embriogénesis somática en Cedro (Cedrela odorata L.) a partir de cotiledones. Tesis Licenciado en Biología. Universidad Nacional Agraria La Molina, Lima, Perú.

Murashige, T., and F. Skoog. 1962. A revised medium for rapid growth and bioassay with tobacco tissue cultures. Physiologia Plantarum 15:473-497.

Orellana, N.M.A. 1997. Desarrollo de un sistema de cultivo in vitro para los explantes nodales de caoba (Swietenia macrophylla King). 94 p. M.Sc. Thesis. Centro Agronómico Tropical de Investigación y Enseñanza (CATIE), Turrialba, Costa Rica.

Patiño, F. 1997. Recursos genéticos de Swietenia y Cedrela en los neotrópicos. Propuestas para acciones coordinadas. 58 p. Organización de las Naciones Unidas para la Agricultura y la Alimentación, Roma, Italia.

Pérez, J., F. Mesén, M. Aguilar, y L. Hilje. 2002. Desarrollo de un método de micropropagación aplicable a genotipos selectos de Cedrela odorata L. Optimización de la fase de multiplicación. Revista Forestal Centroamericana 38:67-71. 
Pérez, J. 2006. Inducing resistance of Spanish cedar (Cedrela odorata L.) and mahohany Swietenia macrophylla K. against Hypsipyla grandella (Zeller) by grafting. p. 149. PhD. Plant Sciences dissertation. University of Idazo, College of Graduate Studies. Centro Agronómico Tropical de Investigación y Enseñanza, Turrialba, Costa Rica.

Pérez, J., F. Mesén, M. Aguilar, y L. Hilje. 2006. Desarrollo de un método de micropropagación aplicable a genotipos selectos de Cedrela odorata L. Fases de desarrollo y enraizamiento. Recursos Naturales y Ambiente 46-47:146-151.

Plasencia, R. 1998. Programa de desarrollo económico forestal hasta el año 2015. Revista Cuba Forestal 1:30.

Ramos, F. 1998. El sector forestal cubano. Revista Cuba Forestal 1:5.
Rodríguez, R., M. Daquinta, I. Capota, D. Pina, Y. Lezcano, y J.L. González-Olmedo. 2003. Nuevos aportes a la micropropagación de Swietenia macrophylla $\times$ Swietenia mahogani (Caoba híbrida) y Cedrela odorata (Cedro). Cultivos Tropicales 24:23-27.

Sasson, A. 2001. Cultivos transgénicos: hechos y desafíos. Monografía. p. 377. Elfos Scientiae, Ciudad de La Habana, Cuba. ISBN: 959-235-019-1.

Schottz, E.S., A.N. Kalil Filho, A.L. Tracs, H. Koehler, L.L. Ribas, and M. Quoirin. 2007. In vitro multiplication of Swietenia macrophylla King (Meliaceae) from juvenile shoots. Ciencia Forestal 17(2):109-117.

Thakur, R.,P.S. Rao, and V.A. Bapat. 1998. In vitro plant regeneration in Melia azedarach L. Plant Cell Reports 18:127-131.

Yanchuk, Y. 2000. Forest biotechnology. FAO Newsletter 12:1-13. 